\title{
Social ideal in the transitional period of Russia's development
}

\author{
Y.A. Elbaev ${ }^{1 *}$, V.G. Trenin ${ }^{2}$, and I.V. Trenin ${ }^{2}$ \\ ${ }^{1}$ Association "Law in Health Care",Moscow, Russia \\ ${ }^{2}$ Russian Union of Afghanistan Veterans, Moscow, Russia
}

\begin{abstract}
The article is devoted to the essence and features of the critical period of social ideal development in the context of the Russian state functioning with the market economy of the transitive period. The philosophical aspects of the social ideal are considered in the historical and personological perspective, its nature, sources, the relationship of structural components - the ideals of social justice, liberty and freedom, Holiness and sacredness, community and conciliarity, strong statehood. The nature of the initial contradiction concluded in the archetype of universal consent and unity, between consent through self-government and consent through domination in the Russian tradition, resolved by a margin in the direction of the second, is shown. Based on the analysis of the Russian philosophers research results, it is shown that the social ideal as an expression and consequence of the national character is manifested at three levels - deep (static), surface (dynamic), superficial (situational).
\end{abstract}

\section{Essence and structure of public ideal}

The historian and ethnographer L.N. Gumilev, the author of the energy theory of ethnogenesis, defined the ideal as "a distant forecast, perceived intuitively" [5]. Philosopher V.E. Davidovich, who developed the "theory of the ideal" in the early eighties, defined the ideal as "an image of perfection, an alluring landmark that people are equal in their activities" [6]. Social scientist A.A. Zinoviev proposed distinguishing between "ideals" - what people strive for (distant goals) and "values" - what people value today. Ideals, in turn, he divided into individual and social [8]. The Russian word 'ideal' is a direct borrowing from the French "ideal" and means something perfect, a higher goal, exalted aspirations. The subject of the ideal development can be not only a person, but also a society. In this case, we are talking about a social ideal. In a broad sense, the social ideal is a consolidated understanding and feeling of the people who form a society of how a society should be perfected; an in-depth request by society of an exemplary scheme of social structure. One of the fundamental features of the social ideal is the ability to manifest oneself as a whole. For the first time, the French scientist E. Durkheim paid attention to the peculiarity of social

\footnotetext{
*Corresponding author: elbaev@mail.ru
} 
systems as a whole, arguing that genetically society arose as a result of the individuals' interaction, but once it emerged, it begins to live according to its own laws [7]. It should be noted that the strategic line for the development of the Russian public ideal is based on the pendulum fluctuations "Economic Efficiency - Social Justice", the swinging of which leads to uprisings, riots, revolutions and civil ones. These oscillations were never strictly symmetrical. The ideal of economic efficiency, embodied in liberal reforms, only briefly fascinated the public consciousness (Alexander II, P. Stolypin, M. Gorbachev, B. Yeltsin), the ideal of social justice always remained dominant, "nuclear," and no political forces could compromise it is an aspiration. However, the idea of social justice does not exhaust the structure of the Russian social ideal. It is fueled by social ideas that have been developing in Russia over the centuries, among which the ideals of liberty and freedom, holiness and sacredness, community and collegiality, and strong statehood are also worth mentioning.

1) The ideal of social justice presupposes, first of all, not material equalization, but equality of social opportunities: equality in education, medical services, legal services, access to information and other social benefits.

2) The ideal of liberty and freemen. The Russian ideal of liberty is different from the Western one, which implies freedom of enterprise, religion, speech and other democratic freedom. Freedom in Russian is, first and foremost, freedom of spirit, a desire for movement in a large continental space, a desire for infinity and reluctance to recognize boundaries and limitations. Hence, Pugachevism craving for uprisings and revolutions, rebellion and disobedience, is described by many domestic and foreign authors.

3) The ideal of holiness and sacredness. We are talking about an irrational belief in certain higher principles of life of both an individual person and the whole Russian society (sacred means holy, divine, treasured, exalted). These principles apply not only to religion, but also to secular life, in particular they apply to economic relations and even politics. The whole Russian mentality is saturated with the spirit of holiness and sacredness. Hence the irrational belief in power, in a good king, whom the people opposed to bad boyars, in the ideals of communism, in just democratic reforms, etc. etc. Power in Russia has always been perceived as something holy, sacred, coming from God. The de-sacralization of power in Russia led to the collapse of power itself and, as a consequence, to the collapse of the state. For example, the overthrow of Nicolai II was preceded by events that disacralized tsarist power: the shooting of a peaceful demonstration with icons on hand (Bloody Sunday), etc.

4) The ideal of community and collegiality. The ideal of community goes back to the Russian peasant community, which collectivist values put above personal values. Community and collegiality are close concepts, complementarily adding each other, but not identical. N.A. Berdyaev tried to express the meaning of the concept of collegiality through the concept of communitarianism, by which he understood the quality, the opposite of closure and isolation. According to Berdyaev, "religious communitarianism is called collegiality, which is the opposite of any authoritarian understanding of the church" $[1 ; 2]$. If we draw a semantic line between the concepts of collegiality and community, then we can say that collegiality is the spiritual side of communism, and community is its everyday, economic embodiment. According to N.A. Berdyaev, the revolution of the 1917 and the subsequent establishment of Soviet power were possible because Lenin and the Bolshevik party played on the communal, collectivist, collegiate chords of the Russian people. The consequence of this social ideal was the Soviet tradition of organizing labor collectives and primary party cells, which were sort of mini-communities united by a "common faith" in socialism, communism; the spirit of collectivism and the principles of personal and family transparency (the professional and personal life of each member of the labor collective was subject to public control). 
5) The ideal of strong statehood. Without a strong and powerful state, Russians as an ethnic group and Russians as a nation simply could not survive. According to the views of Ilyin I.A. a large state can survive and develop only as a strong state [9]. The structure of the Russian state and the ideal of statehood have been honed for centuries, since those distant times when the Golden Horde swept through Russia in a fireball. One and a half years had to pass from the moment of the Battle of the Kalka River (1232) in order to realize the need to build a powerful centralized state, overcome the strife and the first successful attempt at a united rebuff to the aggressor, which was made in 1380 on the Kulikovo Pole. The more difficult it was for a Russian, the more diligently he began to build a state. Almost all wars against Russia ended with the strengthening of Russian statehood. Sometimes this fortification grew into a dictatorship and turned into reprisals against the people (as it was under Ivan the Terrible and Stalin). But, sooner or later, repressions were replaced by relaxation, state structures "eroded", the state weakened and provoked its neighbors with weakness for yet another aggression (after the reign of Ivan the Terrible, "troubles" followed by the subsequent change of the tsar dynasty; after Stalin's death, the Khrushchev's thaw replaced by Brezhnev's stagnation and ending with the Gorbachev's collapse of the USSR).

As a rule, the ideal of strong statehood was closely intertwined with another social ideal - social justice. That is why the Russian people have always painfully endured the unfair distribution of the burdens of serving the homeland and the state. As noted by A.S. Panarin [15], all classes of Russia carried out public service, and it differed "not so much in severity as in the substantial specifics associated with the social division of labor. Ones feed the country, others protect it, the third one - priesthood - maintain a lively presence in it of a high value principle ... "When this principle was violated, discontent arose in society, threatening to develop into a popular rebellion. V.O. Klyuchevsky [12] noted that the peasants expected serfdom to be abolished (and then some social equilibrium would be established), but this did not happen. The situation did not change under Ekaterina II, which resulted in the mass discontent of the peasants, resulting in a civil war known as the "peasant war led by Emelyan Pugachev 1773-1775", when about 40,000 peasants opposed the authorities.

In modern Russia, social injustice is most clearly manifested in the tax system, when state employees bear the main burden, i.e. the poorest segments of the population. For more than 20 years, the introduction of a progressive tax rate and tax on wealth and luxury at the legislative level has been unsuccessful. As the sociologist N. Rimashevskaya notes, a completely new phenomenon has arisen - the polarization and social divide of society in Russia. In fact, two parallel Russia are forming (for the poor and rich), each living their own lives and practically do not interact with each other [17]. Differences in the quality of life of the "two Russia," put Russia at the level of African countries, significantly increasing its social instability. The society intensifies aggression, activates mass deviant behavior (criminality, alcoholism, drug addiction), the potential of protest behavior grows, the process of "erosion" of such moral standards as kindness, mercy, politeness, honesty, responsibility, decency. The danger of such a phenomenon in "ossification" over the course of a number of years of quantitative characteristics of the social stratification of Russian society. This "ossification" shows the inability to rise to the absolute majority of the population from the lower stratum to the upper. That is, almost $40 \%$ of the adult population is in the lower stratum for many years, and have no hopes, including their children rise to middle class. In addition, the lower layer continues to be reproduced and replenished due to "losers" from the middle class. 


\section{Levels of public ideal}

Analysis of the Russian philosophers research results of the Silver Age (P.I. Novgorodtsev, S.N. Bulgakov, N.A. Berdyaev, N.O. Lossky, etc.), as well as modern Russian scientists (L.N. Gumilev, V. V. Nalimov, A.S. Panarin, V.D. Popov and others) shows that the social ideal as an expression and a consequence of a national character is manifested at three levels - deep (static), surface (dynamic), superficial (situational). The static part of the social ideal includes fundamental strategic social ideas that form the basic stereotypes of perception and behavior of one or another local society and significantly affect public life. The ideas discussed above form the "core" of the Russian mentality and, as a consequence, the "core" of the Russian social ideal. The dynamic part of the social ideal includes new and fresh social ideas brought by external contacts with other countries and inter-country associations. "At the superficial level of the social ideal, situational combinations of the ideas of the underlying levels are manifested, associated primarily with radical changes in the external environment of the country.

It seems that the concept of "social ideal" was originally based on two-pronged logic. It can be simultaneously "identified" and "managed". Moreover, the word "reveal" is more applicable to a static, fundamental, strategic social ideal - to its basis. And the concept of "manage" is applicable to the dynamic, external, surface and superficial parts of the social ideal. It is important to emphasize that it is impossible to fundamentally change the static, fundamental part of the social ideal. But it can be destroyed by depriving the ethnos of character, "soul", social dominance, "symbolic capital" and other components of the mental structure.

The above levels of social ideal may have the opposite social "sign", sometimes contradict each other, which has been repeatedly confirmed by the course of Russian history and the unpredictable behavior of the Russian people. The main role here is played by the factors of the Russian social ideal development, which include climate and geography, the real and expected in the future level of passionarity of the Russian superethnos, the deep trends and patterns of development of society, social ideas and ideologies of Western civilization. The listed factors are not completely autonomous, isolated, independent of each other and their separation is carried out in order to obtain the most complete and accurate picture of the structure of the social ideal in Russia. This makes it possible to predict the development of the Russian social ideal in the long-term historical perspective.

It is important to emphasize that modern philosophers $[18 ; 20]$ are inclined to believe that the current development of Russian society in the context of its consolidation through the social ideal is characterized by a slowdown in its civilization self-determination in connection with the most difficult "mix" of the past and new phenomena of modern systemic transformation of society. Since, according to a long-standing Russian tradition, the reforms were constructed on the basis of an "inventory" of the theoretical views of foreign economic schools, the solution of the problems that arose in Russian society were considered through a predominantly "civilization-normative transition" to the development of states with large economies in Western Europe and North America. At the same time, real social practice in Russia led instead of universal access to the benefits of Western civilization and Western consumption standards, to preferences for a limited part of society in the face of a critical decline in GDP, a sharp decline in the quality and standard of living of the majority of the country's population. Therefore, the initial attractiveness of Western democratic values in the public mind acquired a "pendulum" dynamics, and among a significant part of the population acquired a negative meaning. 


\section{Ideal of universal agreement}

Thus, in Russia since the mid-1990s a society began to function with a market economy in the transitional period, but, in general, with elite groups not interested in further systematic democratic transformations. The institutional system that developed under such conditions was distinguished by a mixture of democracy and authoritarianism elements, the dominance of the executive branch at all its levels, and the connection of the competing groups interests of federal and regional authorities' officials and financial associations. Undoubtedly, against the backdrop of the 1998 default, this represented a real danger to the very existence of Russia as a single state, and threatened the transition to the international status of the Third World countries. Under these conditions, the next stage in the evolution of Russian society, which began with the election of V.V. Putin as president, should objectively be the first step in the new consolidation of the central government. This meant introducing the political process into the institutional framework, restoring a clear subordination of state authorities at the federal and regional levels, restoring the functional specialization of power institutions, introducing conciliation decision-making procedures, ending the Cold War between the branches of government and reaching the necessary consensus between them, streamlining the use of state resources and control of central authority over them. In these conditions, the idea of consolidating central authority in a transitional state of society actualizes the key need for the development of a consolidating social ideal that meets not only the interests of individual groups, but above all the population majority of the whole country. Moreover, the social ideal had to meet several basic requirements: compliance with modern realities, reflecting the role and place of Russia in the global world order; reflection and content of answers to modern challenges that Russia faced in the transitional period; the existence of historical continuity of traditional values and traditional institutions of universal unity and harmony in Russian society, formed throughout the entire period of the existence of Russia as a single state.

\section{Is manageable democracy the future of Russia?}

It is important to understand that historically the idea of universal consent is based on several grounds, among which the religious values of traditional religions in Russia Orthodoxy, Islam, Judaism, Buddhism, can be noted. At the same time, the implementation potential even in theoretical terms seems very limited due to their non-state status. But the basic spiritual and moral values of traditional religions can be peculiar regulators of people's behavior in modern Russian society, and to some extent even become systemic in the development of its value system. Another basis may be the institution of the state, which ensures harmony in society. In tsarist Russia, it was an institution of "Godestablished autocratic, tsarist and imperial power"; in the Soviet period - the institution of the "socialist state"; in modern Russia - the institution of the "rule of law". In modern Russia, where the bulk of Russian society supported the line of the country's top leadership to strengthen public administration in almost all areas of the economy, proclaimed as the optimal social institution of "managed democracy" in Russia, it showed the internal stability of its structure and functions as a form, and hypothetically can play the role of a domestic system-forming content for social "framework" and foundations development of a social ideal for the near short and medium term, ensuring the achievement of unity and harmony in society. In addition to the influence of the "managed democracy" domestic institution on the ideas' transformation about the social ideal into the country's stable social ideal, the impact of global and regional civilization challenges of the XXI century, one of 
which is the creation of artificial intelligence in the context of the digital economy development, is of great importance.

The conclusion of foreign authors $[21 ; 22]$ seems to be interesting that in societies making the post-industrial transition, the goal of human production activity is a shift from survival values to values of self-expression. In this sense, in domestic social thought, attention is also paid to the value changes that occur as the post-industrial economy develops. At the same time, an opinion is expressed, argued by examples from different countries that reaching a post-industrial level of development can no longer be connected with authoritarianism, but, on the contrary, should be carried out solely on the basis of further democratic principles development. However, the historical experience of Russia shows that in the Russian public consciousness, both in the past and in the present, liberal democratic values remained and remain the reflective-active product only by certain fractions of the intelligentsia and bourgeois-entrepreneurial groups, without receiving any noticeable distribution, including at the level of political parties and movements. Therefore, it can be assumed that the real severity awareness of this problem by the Russian elite and the thinking part of society will in the long term contribute to the intensification of the search for the national model of post-industrial society; the development of the corresponding social ideal should become an important and necessary element.

\section{Conclusion}

The results of the study show that the initial contradiction, concluded in the archetype of universal consent, between consent through self-government ("democratic consent") and consent through domination ("authoritarian consent") in the Russian tradition, in any case, from the XIV-XV centuries. allowed by an advantage in the direction of the second archetype. But the agreement thus achieved between the authorities and society, the center and the periphery, stemmed from the fundamentally valuable conception of the civilization identity of Russia as a space for the realization of the perfection of being (from the Kingdom of God on earth to communism), which is gaining world power greatness. In other words, public consent through submission to the highest authority was sanctioned by society on the condition of delegating the first authority to implement the timeless transcendental mission of Russia - to be the ultimate attainable perfection on earth, stemming from following either Christian-Orthodox or rationally communist values. It was the revealed imperfection of power, the justification of whose rule was to achieve the perfection of social life, that was the basis for the loss of previous consent, the actualization of the initial contradiction, the exit of the system from a relatively equilibrium state, the systemic crisis and its subsequent resolution through the restoration of its transcendental powers by the new government.

The high degree of continuity of the social ideal content and forms established during this study throughout the self-development of Russian civilization proves the unity of the Russian historical process, the absence, despite elements of an internal socio-cultural split, gaps in the socio-cultural tradition. This suggests that the renewed social ideal of Russian society of the XXI century will contain elements of the social ideals of both the agrarian and industrial stages of the evolution of Russian civilization.

\section{References}

1. N.A. Berdyaev, The origins and meaning of Russian communism (Science M., 1990).

2. N.A. Berdyaev, Russian idea (ABC-classic, SPb., 2008). 
3. S.N. Bulgakov, Two Hail. Research on the nature of social ideals (M. 2008).

3. M. Weber, Protestant ethics and the spirit of capitalism, Selected works. German first. Comp., General editorship and afterword. Y. N. Davydova; Foreword. P. P. Gaydenko. (Progress, M., 1990).

4. L.N. Gumilev, Ethnosphere: History of people and history of nature (M., 1993) 363364.

5. E.V. Davidovich, Theory of the ideal (Ed-in Growth. UN-TA, Rostov-on-don, 1983).

6. E. Durkheim, Sociology. Its subject, method, purpose (TRANS. with FR., compilation, afterword and notes by A. B. Hoffman, Canon, M., 1995).

7. A.A. Zinoviev, On the way to the super-community (ZAO Publishing house Centrpoligraf, M., 2000).

8. I.A. Ilyin, About strong power, Our tasks. Articles years 1948-1954: in 2 t.T. 1. (Irispress, M., 2008).

9. K.D. Kavelin, View of the Russian rural community, Our mental system. Articles on philosophy of Russian history and culture. Appendix to the journal "Questions of philosophy" (Pravda, Moscow, 1989).

10. S. Kara-Murza, Soviet Civilization. Book.1. Book.2 (Algorithm, 2001).

11. V.A. Klyuchevsky, Brief course of Russian history (Publishing house: Exmo-Press, M., 2000).

12. P. I. Novgorodtsev, About social ideals (Publishing house "Press", M., 1991).

13. A.S. Orlov, V.A. Georgiev, N.G. Georgieva, T.A. Sivokhina, History Of Russia (M., 2003).

14. A.S. Panarin, Orthodox civilization in the global world (EKSMO: Algoritm, M., 2003) (JSC Tver. polygon. Combe.).

15. A.P. Parshev, Why Russia is not America (Publishing house: Crimean Bridge-9D, M., 2017).

16. N.M. Rimashevskaya, People and reforms: secrets of survival (M., 2003).

17. Istamgalin Ram Il Safievich, Social ideals of Russian society: philosophical conceptualization (Specialty 09.00.11 - social philosophy. Diss. for the degree of doctor of philosophy).

18. P.A. Sorokin, A. Pitirim Main tendencies of our time [translated from English., poslesl. and pril. T. S. Vasilyeva; Russian Academy of Sciences, Institute of sociology] (Nauka, Moscow, 1997).

19. R.D. Titova, In the Social ideal of modern Russia: philosophical analysis (thesis ... candidate of philosophy: 09.00.11 Federal state budgetary educational institution of higher professional education "Bashkir state University", Ufa, 2015).

20. S.N. Schwartz, Cultural Value Orientations. Nature and Implications of National Differences (Publishing house of SU HSE, Moscow, 2008).

21. R. Inglehart, Modernization and Postmodernization. Cultural, Economic and Political Change in 43 Societies (NJ: Princeton Univ. Press, Princeton, 1997). 